\title{
LÉZERES MÉRÉSEK ALKALMAZÁSA FORGÁCSOLÁSKOR II. - FÚRÁS, MARÁS ÉS ESZTERGÁLÁS LÉZERES VIZSGÁLATA
}

\author{
Béres Miklós \\ mérnöktanár, Miskolci Egyetem, Fizika és Elektrotechnika Intézet, Fizika Tanszék \\ 3515 Miskolc, Miskolc-Egyetemváros, e-mail: mechbere@uni-miskolc.hu
}

\begin{abstract}
Absztrakt
A cikk az első részben (Lézeres mérések alkalmazása forgácsoláskor I. - Monitoring és lézeres érzékelök) felvázolt lézeres méréstechnikák alkalmazásához kiván szakirodalmi példákat bemutatni azért, hogy a klasszikus forgácsolási eljárásokra vonatkozó lézeres mérések lehetöségeire bizonyos rálátást nyújtson. Mindezt az egyes technológiákra vonatkozóan külön-külön teszi. A cikk végén a lézeres mérés néhány olyan problémája kerül elötérbe, amelyet a felhasználáskor mindenféleképpen célszerü figyelembe venni.
\end{abstract}

Kulcsszavak: lézeres mérés, LDV, esztergálás, fúrás, marás

\begin{abstract}
The article intends to present literature examples of the use of laser measurement techniques outlined in the first part (Application of Laser Measurements in Cutting I. - Monitoring and Laser Sensors) in order to provide a certain insight into the possibilities of laser measurements for classical cutting processes. It does this individually for each technology. At the end of this article, some problems with laser measurement are brought to the fore that should be taken into account when using them.
\end{abstract}

Keywords: laser measurement, LDV, turning, drilling, milling

\section{Bevezetés}

A gyártási rendszerekben kiemelt szerep jut a hatékony termelékenység fenntartásának. A mutatók növekedésének mozgatórugója a gyártási idő csökkentése. Ennek egyik módja az egyes termelési lépések felgyorsítása, például a megmunkálási sebesség növelése. Ez azonban újabb problémákat vet fel. Gyártórendszerekben a folyamaton belüli metrológia ugyanakkor lehetővé teszi a pontosság javítását és a megmunkálási idő csökkentését az áthelyezési és beállítási mủveletek kiküszöbölésével [1]. vagy állapotfelügyeleti rendszerek bevezetésével.

Jelen cikkben az első részben (Lézeres mérések alkalmazása forgácsoláskor I. - Monitoring és lézeres érzékelők) felsorolt lézeres méréstechnikák néhány alkalmazása kerül bemutatásra az egyes megmunkálások szerint, esztergálásra, fúrásra és marásra. Ezek a lézeres mérési eljárások érintkezés nélküli pontos információszerzést tesznek lehetővé. Így akár a gyártási folyamat közben is lehetővé válik egy újabb független jelforrás, mellyel akár potenciálisan helyettesíthető néhány korábbi mérési eljárás is.

Az említett lézeres eszközök közül a trianguláris mérőeszköz az iparban ma már elterjedt eszköznek számít, legyen szó akár hegesztőfej pozicionálásról, robotmozgatásról, útfelületellenőrzésről vagy akár rétegvastagság vizsgálatról, stb. [2]. De a gépgyártásban is egyre több példát találunk. 
Az LDV-s mérések az elmúlt időszakban hatalmas fejlődésen mentek keresztül. A fordulatszám ellenőrzésen keresztül egészen a 3D-s mérésekig számtalan alkalmazása ismert [3]-[5], és egyre gyakrabban fordulnak elő gyártó eszközök, folyamatok vizsgálatában is. Az 1. ábra ultraprecíziós megmunkálások esetén felhasznált érzékelőkről ad felvilágosítást. A vízszintes tengely nemcsak az érzékelők által megfigyelt paramétereket, hanem egyúttal az egyes érzékelőtípusok mérési frekvenciatartományát is mutatják. Meg kell jegyezni, hogy az ábra inkább tájékoztató jellegü. Egyes különleges esetek ettől az általános besorolástól eltérhetnek.

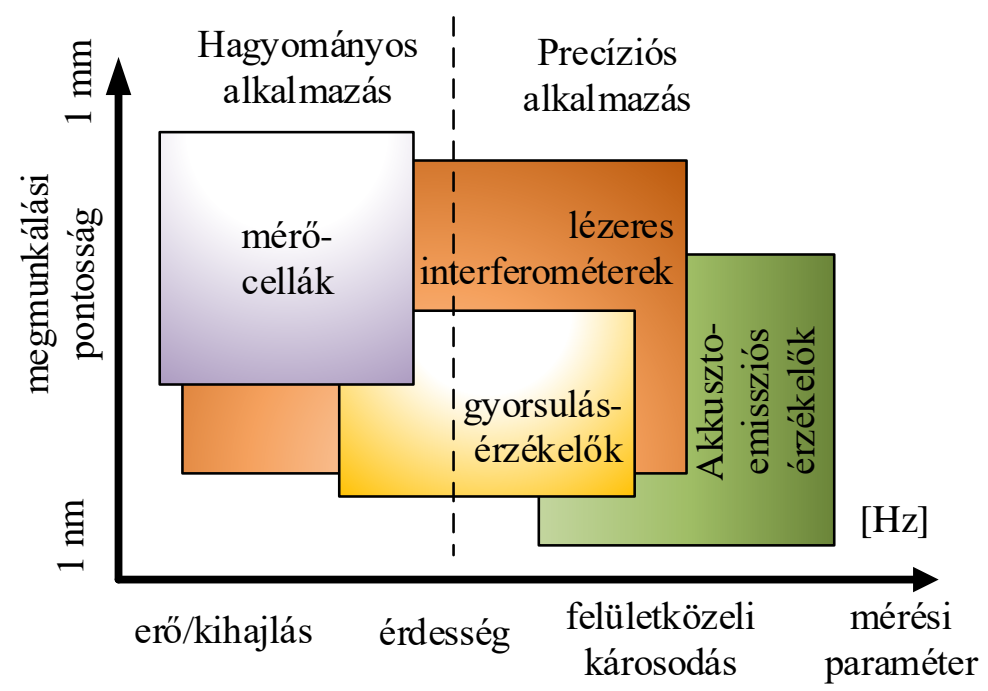

1. ábra. Ultrapreciziós megmunkálásnál monitoringhoz használt érzékelök ([6]alapján)

\section{Lézeres mérés esztergálásnál}

Az esztergálás mint az egyik legrégebbi megmunkáló eljárás gyakran képezi vizsgálat tárgyát. Sok bevált mérési módszer alakult ki tanulmányozására. Jellemzően a főorsó áramfelvétele alapján számolt teljesítményfelvételét használják az állapotfelügyelet alapját képező bemeneti paraméterként. A teljesítményalapú TCM (Tool Condition Monitoring) elsősorban azonban a szerszám élettartama végső állapotának azonosítására használható; és kevésbé felel meg a szerszámtörés és hasonló egyéb hirtelen események hatékony észleléséhez [7].

Esztergálásnál a lézerrel egyszerübb méréseknél is találkozhatunk. Korai és ma is előforduló alkalmazása fordulatszám-mérőként történik. Mindenekelőtt az implementálása egyszerü, akár a tokmányról levett jelet is mérhetjük vele. Urbakain és társai is így használták a lézert, amikor az SSV (orsósebességvariációs technika) gyakorlati megvalósítási lehetőségeit vizsgálva CNC eszterga központon méréseket végeztek [8]. A jobb stabilitási határok és az orsó elfogadható viselkedése közötti egyensúlyt itt is az energiafogyasztás mérése biztosította. A visszaszabályozáshoz pontos fordulatszámadatokra volt szükség. Ezen adatokat a lézer szolgáltatta - sikeresen.

Másik felhasználásaként mint felületi letapogatási módszert kell megemlítenünk. Nemcsak az esztergálásnál, hanem egyéb forgácsolási megmunkálásnál is alkalmazott eljárás. A szerszám és a megmunkált felület ellenőrzésére egyaránt alkalmazott eljárás. Kiss Ádám és kollégái nemrég megjelent cikkükben esztergálásnál fellépő öngerjesztett rezgések okaira kerestek választ [9]. A megmunkálási 
folyamat során keletkező rezgések dinamikus viselkedésének jellemzőit a megmunkált felület érdességének méréséből származó eredményeknek az elméleti összefüggésekkel történő összehasonlításából nyerték. Erre a célra ipari lézeres differenciál elmozdulás mérőt alkalmaztak, amellyel mérték a felület eltérését az ideális geometriától. A legtöbb felület esetében ugyanis a normál tükröződés és a diffúz visszaverődés aránya felület érdességének függvénye. Ennélfogva a visszavert fényminta a felület jellemzőire vonatkozó információkat hordoz. Méréseik során az érzékelő megfelelő pontosságot biztosított a detektáláshoz. Korlátként merült fel, hogy a lézerfolt nem ideális pont, hanem ellipszis alakú. Mivel az érzékelő a felület érdességének átlagát méri - ráadásul nem szimmetrikusan - ez a hatás valóban mint mozgó átlag jelentkezik a mérés vonala mentén. A folt asszimetriájával gyakran akkor találkozunk, ha a müszer félvezető lézert használ. Ilyen esetben mérlegelni kell a mérési távolságot. A térbeli módusú félvezető szilárdtest lézereknél (SD) ugyanis a félvezető lézer sugár mind az aktív rétegre merőleges irányban, mind azzal párhuzamosan csak megfelelő távolságból tekinthető Gauss-eloszlásúnak [10], vagy Lorenz-eloszlásúnak [11]. Ezért ezeknél a méréseknél - a lézer típusa miatt - a mérési távolság mindig problematikus.

Hasonló lézeres alkalmazás szerepelt Wong és kutatócsoportjának egy korábbi kísérletsorozatában [12]. Cikkükben olyan optikai módszert mutattak be, amely a visszavert lézerfény szórási mintázatát használja fel a szerszám állapotának nyomon követésére, nagyolás esetén. A mérés során egy kis teljesítményü He-Ne gázlézer fénysugara verődött vissza a munkadarab felületéröl, melynek szórt fényét digitális fényképezőgéppel rögzítették, majd a megfelelő képfeldolgozási technikákkal elemeztek. A kapott mintázat átlagát és az intenzitásképre vonatkozó szórását vizsgálták. Ezzel a módszerrel akár a lézer hullámhossza 1/8-ának megfelelő érdességet is detektálni lehet. Természetesen ahhoz, hogy a szerszám kopását elemezni lehessen, a felület minőségét, az optikai paramétereket és a szerszámdegradációt illeszteni kellett egymáshoz. Tapasztalataik szerint a felületi minőség, a szerszámkopás és az optikai jellemzők nem mindig vannak teljesen összhangban egymással, mert számos faktor függvénye. A szórt lézermintázat önmagában nem korrelál a szerszámkopással, a minta intenzitáseloszlása viszont igen - de csak a kopás korlátozott tartományában.

Öngerjesztett rezgéseket vizsgáltak Prasad és társai, de már egy LDV-vel végzett kísérletsorozat során. Tanulmányukban [13] a munkadarab rezgése, a szerszám kopása, és a megmunkált felület texturája között keresték a kapcsolatot. Homlokesztergálásnál lézerrel mérték az előtolás irányú rezgést. A kapott jelből FFT spektrumot képeztek, majd azt kiértékelték. Különböző anyagokon, az éles, majd a kevésbé kopott, végül az életlen szerszámmal elvégezve a méréseket azt tapasztalták, hogy a szerszám kopásának előrehaladtával a frekvenciatartományban is - az elvárásoknak megfelelően - emelkedtek a rezgési amplitúdók. A rezgés további növekedése a munkadarab és a vágószerszám között fellépő egyre nagyobb súrlódóerőnek tulajdonították, amely egyúttal a szerszám kopásának a következménye.

Prasad egy másik cikkében a forgácsolási körülmények közül egyszerre használták fel a forgácsolási hőmérsékletet és a rezgésjelek dinamikai jellemzöit [14]. Az előtolásirányú rezgések adatainak kinyerésére ortogonális forgácsolásnál LDV-t használtak, a hőmérsékletet pedig infravörös termográfiai módszerrel mérték. Céljuk egy kísérleti adatbázisnak a létrehozása volt a szerszám kopásának detektálására és nyomon követésére. Kísérleteik során kapcsolatot mutattak ki a rezgések, forgácsolási hőmérséklet és a szerszámkopás közt, a fordulatszám függvényében.

Az esztergáláshoz köthető, de már a következő fejezetet is érinti Venkata Rao és munkatársai cikke [15], amelyben a szerzők a forgácsolási sebesség, az előtolás és a forgácsolólapka csúcssugarának hatásait elemezték furatesztergálásnál. A rezgések ennél az eljárásnál különösen abban az esetben jelentenek problémát, amikor a szerszám még a furatmegmunkálás kezdeténél tart, s nagy része a furaton kívül 
helyezkedik el. Az LDV-vel szintén a munkadarab rezgését figyelték, majd a jel FFT spektrumát felvéve összehasonlították az érdességi, kopási paramétereket a rezgési amplitúdókkal.

Furatesztergálás közben olyan esetben is végeztek lézeres méréseket, amikor a megmunkálási eljárást kívülről generált rezgések segítik [16]. Chern és Liang piezo-kristályos rezgetőt használva a szerszámot előtolás irányban rezgette. Céljuk a keresztező furatok minőségi javítása, valamint a felületi érdesség csökkentése volt. A furatok kereszteződésnél ugyanis akár jelentős sorjázatok is kialakulhatnak, melyek például szelepeknél áramlástechnikai gondot okoznak. Vizsgálataikban a lézernek kiegészítő szerep jutott. Lézeres elmozdulásmérővel a rezgési amplitúdókat elemezték. A mintavételezési frekvenciája $50 \mathrm{kHz}$ volt, míg a szerszámot gerjesztő frekvenciát $14 \mathrm{kHz}-i g$ tudták változtatni, így egész magas frekvenciákat is vizsgálni tudtak.

\section{Fúrás lézeres mérése}

Az elöző két anyagleválasztási müvelethez képest a fúrásnál még kevésbé jellemző, hogy lézert érzékelő jelforrásként használnák. Az utóbbi időben ugyan több cikk is megjelent az LDV fúrás közbeni alkalmazásával kapcsolatban [16][17][18], de korántsem mondható gyakran felhasznált módszernek. Előnyei pedig éppen ennél az eljárásnál válhatnának dominánssá.

Elektronikusan érintés nélküli mérési technikák, például induktív és kapacitív elmozdulás-érzékelők korlátozott lehetőséget nyújtanak érintés nélküli mérésre. Ezek csak a közeli mérésekre korlátozódnak, és érzékenyek a hőtágulásra, ezért két párba kell őket rendezni [19]. A fúrásnál nincs lehetőség a forgácsolás folyamatának közvetlen ellenőrzésére - mivel az közvetlenül nem figyelhető meg. Így csak közvetett mérési eljárások segítenek a munkavégzés közbeni jelenségek megértésében, akár egy TCM stratégia megalkotásában. Részben ez is oka, hogy a szerszám, és nem a munkadarab rezgéseit célszerü vizsgálni [20]. Ha magát a szerszámot mérjük, jobban megfigyelhetőek az egyes forgácsleválasztási lépések.

A 453 fejezetben is megemlített kísérleteiben Chern és Liang például kis átméröjü furatok esetére is megismételte ugyanazokat a rezgésvizsgálatokat, amelyeket furatesztergálás során is már elvégzett. A felhasznált lézeres elmozdulásmérő méréstartománya $(50 \mathrm{kHz})$ tette lehetővé, hogy a nagyobb frekvenciatartományban használt gerjesztést megfelelöen tudjuk mérni.

Fúrás közbeni méréseknél jól megfigyelhető volt, hogy addig, amíg (megkötött forgácsolási paraméterek mellett) a fúrószár teljes átmérővel el nem kezd forgácsolni, az egyes időbeli fázisok meghatározott időbeli és frekvenciabeli tartománnyal rendelkeznek [18].

Balaji és társai a forgácsolási sebesség, az előtolás és a horony hajlásszögnek a szerszám élettartamára (kopására) gyakorolt hatásával foglalkozik fúrásnál [21]. Tanulmányában egyetemes esztergán végrehajtott fúrás közben vizsgálta a szerszám rezgéseit Lézer Doppler regésmérővel. A mért adatok alapján állapította meg a rezgésamplitúdók, valamint a kopás, a horonyszög, a felületminőség valamint a rezgési paraméterek közötti kapcsolatot.

\section{Lézeres mérések marásnál}

A marás az a forgácsolási mủvelet, amelyet talán felhasználási sokoldalúsága miatt leginkább kutattak/kutatnak. Vizsgálatakor ezért is találkozunk gyakrabban lézeres eszközökkel.

Ryabov és munkatársai egy korai munkájukban [22] lézert alkalmaztak folyamat közbeni szerszámkopás mérésére, továbbá közepes és nagyobb szerszámhibák detektálására. Valós forgácsolási körülmények között kapott zajos jelek mérésének alapját lézeres elmozdulás-érzélkelők adták és két lézer-szenzort használtak egyszerre. A két lézerrel a szerszám vágóélének alakjának ellenőrizték. Mindemellett a 
kapott jeleket az ellenőrző rendszerbe betáplálva, a fordulatszám-szabályozás szinkronizációs jeleként is felhasználták. Tapasztalataik szerint a felületről történő visszaverődés jellemzői függenek a felület fénydiszperziós tulajdonságaitól, és a beeső fénysugárhoz viszonyított irányától. A gyakorlati méréseknél kapott eredmények alapján a normál és a kopott felületek egyértelmüen megkülönböztethetők a felület különbségéből fakadó fényintenzitási mintázatokon keresztül. Bár diszperziós tulajdonságaikban nem különböznek jelentősen.

Tatar és Grin által írt cikkben szintén a szerszám rezgéseinek elemzésével találkozhatunk, gyorsmarásnál [19]. Mivel nagysebességü forgácsolás esetén a föorsó rezgésmérésekor, az alacsony rezgésjel átvitel, a csapágyak zavarai és a motor mágneses zavarai megbízhatatlanná teszik a klasszikus méréseket, ezért új érzékelőt választottak. A szerszám közelében elhelyezett érintés nélküli lézeres érzékelővel oldották meg a feladatot. Kísérleteiknél az LDV nemcsak nem csak a szerszám adott pontjának a sebességét mérte, hanem a beépített rendszernek köszönhetően, az elmozdulását is. Ez a lehetőség az alsó frekvencia tartományban jelent igazán előnyt. Ugyanakkor a pszeudo-rezgések megjelenése, továbbá a szerszámszár alakjából származó keresztrezgések miatt, kiegészítő méréseket kellett végezniük.

Faassen és társai által készített munkának a témája is nagysebességủ marásnál fellépő, öngerjesztett rezgések voltak [23]. Míg mások a gép dinamikájának és a forgácsolási folyamat viselkedésének leírására állandó paramétereket használnak a teljes főorsó fordulatszám tartományára, ők olyan modellt javasoltak, amely a stabilitási térképek megszerkesztéséhez figyelembe veszi a főorsó fordulatszámot is. Ebben a modellben a gép dinamikája is szerephez jut. A főorsó-szerszámtartó-szerszám rendszer dinamikus viselkedésének mérésére, valamint az orsó sebességének e viselkedésre gyakorolt hatásának megismerésére impulzus kalapáccsal FRF (Frequency Response Function) teszteket hajtottak végre. Álló és forgó föorsó mellett végeztek méréseket, ahol a rezgéseket ikerszenzoros ipari lézeres (LTS - Laser Twin Sensor) felületvizsgáló érzékelővel vették fel. A lézeres mérés révén 750-1750 Hz tartományban tudtak felállítani frekvencia válasz karakterisztikát. A stabilitási határok finomításához az előző kísérletek náluk is kiegészültek, mégpedig mikrofonos mérésekkel.

Marógépen készültek Rantatalo mérései is [24]. Módszere elsősorban a főorsó rezgéseinek elemzésére irányult. Komplex munkájában a főorsónak, mint forgó elemnek a rendszer stabilitására gyakorolt hatására keresett választ. Megoldása általános, ezért egyéb tokmányba befogott eszköznél is használható.

A főorsó forgácsolásra gyakorolt dinamikai hatásával Österlind és kutatócsoportja is foglalkozott [25], de másoktól eltérően az folyamat közbeni modális elemzés módszerét (OMA - Operational Modal Anaqlysis) használta fel. Statikus méréseknél impulzuskalapáccsal készültek az átviteli függvények, majd OMA-val a müködés közbeni paramétereket rögzítették. Kísérleteiknél ők is több különböző érzékelőt használtak. A munkadarab, a szerszámbefogó és az asztal rezgéseit gyorsulásmérőkkel, míg a szerszám rezgésekre adott válaszát lézer Doppler rezgésmérővel mérték. A mérési eredményeket a rendszer stabilitási térképének elemzéséhez használták fel, vizsgálva a forgácsolás közben az abban bekövetkezett változásokat.

Az öngerjesztett rezgések, mint téma régóta foglalkoztatja a kutatókat. Például Nakagawa és társai egy korábbi cikkükben edzett acélanyagok marásakor keletkezett rezgések felületminőségre gyakorolt hatásait tárgyalják [26]. Mivel a korábban szóba került örvényáramos érzékelőnek egyrészt elhelyezési, másrészt dinamikai jellegü hátrányai voltak (alsó frekvenciatartománybeli érzékelési küszöb) ezért egy LDV-vel mérték meg a marószerszámvég elmozdulását. Méréskor egyszerre két LDV figyelte a műveletet, illetve a szerszámvég egymásra merőleges elmozdulásait. A müszer relatív mérési hibáját azzal 
igyekeztek korrigálni, hogy a mérési ponttól viszonylag távolra helyezték el a müszert. Kísérleteik során, jó felbontású mérések segítségével sikerült beazonosítani két, különböző típusú öngerjesztett rezgést is, valamint jól meg lehetett figyelni a stabilitási térkép instabil tartományainak változását.

A szerszámgép-szerszám-munkadarab rendszer dinamikai tulajdonságait vizsgálták Norman és társai is, amelynek során a rendszer dinamikai paramétereinek előzetes meghatározására LDV-t használtak [27]. Mivel a szerszámgép merevsége a változó megmunkálási körülmények miatt maga is változik (pl. a változó csapágymerevség fordulatszámfüggő volta miatt), ezért vizsgálataikhoz próbapadot készítettek. Ezen kerültek ellenőrzésre a rendszer dinamikáját befolyásoló különböző tényezők hatásai Eltérő terhelési eseteket vizsgálva az LDV-vel mért válaszadatokat kísérték figyelemmel. Úgy határozták meg tehát a rendszer átviteli függvényét, hogy közben a föorsó tengelye mindvégig forgásban - azaz munka közben - volt. Kísérleteik eredményei alátámasztották az érintés nélküli módszerekkel történő vizsgálatok azon előnyét, hogy a mérésnél nem lépnek fel a hagyományos érzékelőknél megfigyelt hátrányok, például a gyorsulásmérők tömegterhelése vagy az impulzuskalapács fejének csillapítása okozta hiba. A méréseket tehát akár a szerszám forgása közben is el lehet végezni, úgy, hogy közben nyomon követhetô a rendszer különböző forgási sebességeknél meghatározott átviteli függvényeinek változásait.

\section{Közös tapasztalatok a lézeres mérésekkel kapcsolatban}

Mint minden érzékelőtípusnál, a lézeresnél mérési hibát okoznak a beépítésük körülményei, mivel a mért sebességjel relatív. Az LDV-s mérőmüszerrel végzett kutatási célú megmunkálási kísérletek során gondot jelent, hogy a készüléket (méreteiből adódóan) gyakran állványra szerelten tudják csak használni [17][28]. Tehát az LDV kimenetén azoknak a rezgéseknek a hatása is megjelenik, amely a lézer „felfogatási” körülményeiből származnak [29][30]. A kézenfekvő megoldásként kínálkozó, környezettől való elszigetelés azonban gondos előkészítést igényel. Ráadásul alacsony frekvenciák kiküszöbölése esetén igen körülményes. Így nem oldja meg maradandóan ezt a gondot. Bizonyos esetekben egyáltalán nem küszöbölhető ki. A szerző több társával együtt például egy optikai rezgésmentes asztal segítségével, több különböző mérési összeállításban végzett mérései során olyan rezgéseket is tapasztalt, amelyek még az állvány megválasztásától is függetlenek, magának a mérőeszköznek a jellemzőitől, kialakításából származnak [29].

A probléma azonban felfogható lézertechnikai feladatként is. Norgia és társai egy olyan új önkeverő (self-mixing) interferométert javasolnak, amely az abszolút távolság és az abszolút sebesség egyidejü mérését is el tudja végezni [31]. Lézeres mérési elrendezésük ipari környezetben is alkalmasnak tünik a rendszeres használatra. További előnye, hogy a mérési sebességet a módszerrel meg tudták növelni. Ezáltal lehetőséget kínál akár egy szórásmintázati hiba okozta, megbízhatatlan mérési adatnak a valós időben történő elvetésére is.

A sebességjel relativitására, mint hibaforrásra kínál egyszerủ megoldást Halkon és Rothberg elgondolása [32]. Kísérleteikben a müszert két, a rezgésirányt mérő hagyományos gyorsulásérzékelővel egészítették ki. Gyakorlatilag bebizonyosodott, hogy ha egy, a müszerre tetszőleges helyen felszerelt, a lézersugár irányába illesztett gyorsulásmérőt párosítanak egy vele azonos irányban mérő, és a lézersugárra tengelyszimmetrikusan elhelyezkedő második gyorsulásérzékelővel, akkor a müszer saját rezgéseinek amplitúdó- és fázisspektrumai jól korrigálhatók. Ezen kedvező tapasztalatok mellett azonban a korrekciót ronthatja a gyorsulásérzékelő keresztirányú érzékenysége.

Nemcsak a mérés relativitása okoz problémát azonban, hanem a lézerfény polarizált koherens volta is. Ezen tulajdonságú fényhullám esetén ugyanis, ha a fény optikailag durva felületet világít meg- és 
ilyen a legtöbb felület -, akkor minden egyes apró felületelem koherens fényü pontforrásként fog viselkedni. Az így keletkezett korrelálatlan fényhullámok által, a szuperpozíció eredményeként sötét és világos foltok szemcsés mintázata alakul ki a detektoron. Az érzékelő több ilyen, u.n. foltmintát gyüjt össze egy-egy mintavételezési alakommal, s a fotodióda áramkimenete ezeknek a pillanatnyi intenzitáseloszlásoknak az összegével lesz arányos [33]. Ha a foltmintázat térbeli és időbeli változásokon megy keresztül (például a céltárgy mérési irányra merőlegesen gyors elmozdulása, vagy hirtelen elfordulása), a Doppler-jel - így a detektor kimenete is - modulálódik a mintázat változása révén [5], [34]. A mintázati zaj kialakulása tehát azzal magyarázható, hogy a rezgés során a lézer által megvilágított pont a teljes mozgásidőszak alatt nem volt ugyanaz a pont [35]. Önmagában az interferencia-mintázat hasznos tulajdonság lenne például ha a felület minőségének vizsgálatáról lenne szó. De a rezgésvizsgálat esetén kifejezetten hátrányt jelent, mert a minta közel véletlenszerü módon ingadozik [17][19][36]. A szemcsézettség változásának mért jelre gyakorolt hatása ugyan a mérések átlagolásával csökkenthető [37][38], azonban a mintázat forgás révén bekövetkező ,ismétlődéséből” megjelenő álrezgések továbbra is láthatóak a spektrumban. Nemzetközi szakirodalomban használt elnevezésük: pszeudo-rezgések [39][51]. Ha tehát a lézer nagy sebességgel forgó munkadarabot vagy szerszámot pásztáz, akor a frekvenciaspektrumban az effektus miatt zavaró csúcsokat és magasabb rendủ harmonikusokat fogunk kapni [5][33], [38].

Ezen probléma legegyszerübb megoldására úgy tünik, hogy a mérésekhez „optikailag sima” felület készítése lehet jó megoldás [19][27][36]. Azaz egyrészt megtisztított, másrészt simára csiszolt felületet kell kialakítani a jó visszaverődéshez. Ilyen előkészítésre, vagy ezen feltétel tartós biztosítására azonban nincs mindig lehetőség. A kérdés érdekes hasonlóságot mutat a távmérésnél (vagy lézer alapú távérzékelés - LIDAR - Light Detection and Ranging) jelentkező foltzaj jelenségnél tapasztaltakkal. Courville és Sava, bár nem a fémforgácsolás területén dolgozva, munkájában felhívja a figyelmet arra, hogy egyetlen LDV, amely két, egyvonalban megfelelően elhelyezett detektorral rendelkezik, egyidejűleg két mérést rögzíthet, melyek független foltzajjal fognak rendelkezni [41]. Ezáltal rögzíthetik a fény ortogonális polarizációját is. A folt zajának csökkentésére a frekvenciatartományban való jelelválasztást, és az egyszerre több érzékelővel felvett mérési sorozat átlagolását javasolják.

Vass és kutatótársai olyan időtartományban müködő algoritmust fejlesztettek ki, amelynek révén a visszavert fény jel/zaj aránya javítható [42]. Kísérleteik szerint ha a visszavert fény foltmintázata jelentősen eltér a jelben szereplő minták többségétől (időben vizsgálva), vagyis a minta amplitúdóeloszlása nem követi a jel szokásos szóródását, és rendkívüli eltérést mutat az átlagtól, akkor a csúcsosság (kurtózis) felhasználható a zavar detektálására. Ha a kiugró értékek egy határt túllépnek, automatikusan eltávolíthatók. Hasonlóan korlátot fogalmaz meg a rezgési amplitúdókra Hosek is, aki többféle technikával hasonlította össze e módszer hatékonyságát [34]. A kurtózis módszer hátránya, hogy elsősorban a véletlen és az átlagból kiugró szóródási zaj felismerésére alkalmas.

A forgás okozta zajfoltosodási hibák kiküszöbölésére egy további, egyszerü megoldás szinte magától kínálkozik. Ha a forgácsolási körülmények megengedik, akkor az álló szerszámon kell elvégezni a mérést [15][16][17][20]. Ez a korlát azonban nem lehet feltétele az állapotfelügyeleti stratégia kialakításának.

\section{6. Összefoglalás}

Jelen mü nem kívánt teljes betekintést adni a lézeres mérések hagyományos forgácsleválasztásos gyártástechnológiáknál történő felhasználására, csupán a legismertebb, vagy a gyakorlatban többször előforduló lehetőségeket tekintette át. 
Összefoglalásként elmondható, hogy a lézeres mérőberendezések a különböző megmunkálásoknál változatosan kerülnek felhasználásra. A gépgyártástechnológiai eljárások közül fúrásnál a lézerek alkalmazása még várat magára. Ellentétben a marással vagy az esztergálással, mely jól, és eredményesen kutatott területek. Lézerek felhasználása elsősorban a felületvizsgálat, felületellenőrzés és a géprendszer, vagy folyamat dinamikai viselkedésének meghatározásakor került előtérbe.

A gyakorlatban jól bevált trianguláris méréstechnika megfelelően használható a forgácsolás közben történő mérésekhez is. Az interferometriás mérőeszközök a többi lézeres méréstechnikához képest ugyan pontosabbak, de bonyolultabb kiépítésük miatt kényesebbek a körülményekre. Kutatásra gyakran alkalmazott módszer, de gyártás közben jelenleg szinte csak pozicionálási, koordinátamérési esetekben használják.

Jellemző, hogy a lézeres méréstechnika inkább egy összetettebb mérőrendszernek egyik alkotóeleme csupán, s más típusú mérőeszközök mellett kiegészítő szerepet kap.

Igaz, hogy a forgácsolási vagy megmunkálási körülmények nem mindig kedveznek az olyan méréstechnikai módszereknek, ahol a környezeti hatások erősen befolyásolhatják a mérés eredményeit. A lézeres technika azonban a maga előnyeivel, a forgácsolás közben felvetődő problémákra is egyre inkább alkalmas megfelelö választ adni.

\section{Köszönetnyilvánítás}

A cikkben ismertetett kutató munka az NKFI-125117 számú projekt a Nemzeti Kutatási Fejlesztési és Innovációs Alapból biztosított támogatással, a K_17 pályázati program finanszírozásában valósult meg.

\section{Irodalom}

[1] T. Nishiguchi, Y. Koizumi, Y. Maeda, M. Masuda, K. Nagayama, and K. Okamura, "Improvement of Productivity in Aspherical Precision Machining with In-situ Metrology" CIRP Ann. - Manuf. Technol., vol. 40, no. 1, pp. 367-370, 1991. https://doi.org/10.1016/S0007-8506(07)62008-3

[2] W. Gao et al., "Measurement technologies for precision positioning" CIRP Ann. - Manuf. Technol., vol. 64, no. 2, pp. 773-796, Jan. 2015. https://doi.org/10.1016/j.cirp.2015.05.009

[3] T. J. Miles, M. Lucas, N. A. Halliwell, and S. J. Rothberg, "Torsionaland bending vibration measurement on rotors using laser technology" J. Sound Vib., vol. 226, no. 3, pp. 441-467, Sep. 1999. https://doi.org/10.1006/jsvi.1999.2253

[4] S. J. Rothberg and N. A. Halliwell, "Vibration measurements on rotating machinery using laser doppler velocimetry" J. Vib. Acoust. Trans. ASME, vol. 116, no. 3, pp. 326-331, 1994. https://doi.org/10.1115/1.2930432

[5] S. J. Rothberg et al., "An international review of laser Doppler vibrometry: Making light work of vibration measurement" Opt. Lasers Eng., vol. 99, pp. 11-22, Dec. 2017. https://doi.org/10.1016/j.optlaseng.2016.10.023

[6] D. A. Dornfield, Y. Lee, and A. Chang, "Monitoring of ultraprecision machining processes" Int. J. Adv. Manuf. Technol., vol. 21, no. 8, pp. 571-578, 2003. https://doi.org/10.1007/s00170-002-1294-2

[7] M. S. H. Bhuiyan and I. A. Choudhury, "Review of Sensor Applications in Tool Condition Monitoring in Machining" in Comprehensive Materials Processing, vol. 13, Elsevier Ltd, 2014, pp. 539-569. https://doi.org/10.1016/B978-0-08-096532-1.01330-3 
[8] G. Urbikain, D. Olvera, L. N. L. de Lacalle, and A. Elías-Zúñiga, "Spindle speed variation technique in turning operations: Modeling and real implementation" J. Sound Vib., vol. 383, pp. 384-396, Nov. 2016. https://doi.org/10.1016/j.jsv.2016.07.033

[9] A. K. Kiss, D. Bachrathy, and G. Stepan, "Laser scanned patterns of machined surfaces" in Procedia CIRP, 2018, vol. 77, pp. 355-358. https://doi.org/10.1016/j.procir.2018.09.034

[10] H. Sun, "Modeling the near-field and far-field modes of single spatial mode laser diodes" Opt. Eng., vol. 51, no. 4, p. 044202, Apr. 2012. https://doi.org/10.1117/1.0E.51.4.044202

[11] A. Naqwi and F. Durst, "Focusing of diode laser beams: a simple mathematical model" Appl. Opt., vol. 29, no. 12, p. 1780, Apr. 1990. https://doi.org/10.1364/AO.29.001780

[12] Y. S. Wong, A. Y. C. Nee, X. Q. Li, and C. Reisdorf, "Tool condition monitoring using laser scatter pattern" J. Mater. Process. Technol., vol. 63, no. 1-3, pp. 205-210, Jan. 1997. https://doi.org/10.1016/S0924-0136(96)02625-8

[13] B. S. Prasad, M. M. M. Sarcar, and B. S. Ben, "Development of a system for monitoring tool condition using acousto-optic emission signal in face turning-an experimental approach" Int. J. Adv. Manuf. Technol., vol. 51, no. 1-4, pp. 57-67, Nov. 2010. https://doi.org/10.1007/s00170-010-2607-5

[14] B. S. Prasad, K. A. Prabha, and P. V. S. G. Kumar, "Condition monitoring of turning process using infrared thermography technique - An experimental approach" Infrared Phys. Technol., vol. 81, pp. 137-147, Mar. 2017. https://doi.org/10.1016/j.infrared.2016.12.023

[15] K. V. Rao, B. S. N. Murthy, and N. M. Rao, "Experimental study on tool condition monitoring in boring of AISI 316 stainless steel" Proc. Inst. Mech. Eng. Part B J. Eng. Manuf., vol. 230, no. 6, pp. 1144-1155, Jun. 2016. https://doi.org/10.1177/0954405414565139

[16] G. L. Chern and J. M. Liang, "Study on boring and drilling with vibration cutting" Int. J. Mach. Tools Manuf., vol. 47, no. 1, pp. 133-140, Jan. 2007. https://doi.org/10.1016/j.ijmachtools.2006.02.017

[17] M. Béres and B. Paripás, "Measuring of drill bit vibration by laser Doppler methods" in IOP Conference Series: Materials Science and Engineering, 2018, vol. 448, no. 1. https://doi.org/10.1088/1757-899X/448/1/012068

[18] M. Béres and B. Paripás, "Fúrószár rezgéseinek mérése lézer doppler módszerrel" MultiScience - XXXI. microCAD International Multidisciplinary Scientific ConferenceUniversity of Miskolc, Hungary, $\quad 20-21 \quad$ April $2017 \quad$ ISBN $978-963-358-132-22018$. https://doi.org/10.26649/musci.2017.053

[19] K. Tatar and P. Gren, "Measurement of milling tool vibrations during cutting using laser vibrometry" Int. J. Mach. Tools Manuf., vol. 48, no. 3-4, pp. 380-387, Mar. 2008. https://doi.org/10.1016/j.ijmachtools.2007.09.009

[20] M. Béres and B. Paripás, "Measurements of vibration by laser doppler method in the course of drilling" in Lecture Notes in Mechanical Engineering, vol. 0, no. 9783319756769, Pleiades Publishing, 2018, pp. 199-208. https://doi.org/10.1007/978-3-319-75677-6_16

[21] M. Balaji, B. S. N. Murthy, and N. M. Rao, "Optimization of Cutting Parameters in Drilling of AISI 304 Stainless Steel Using Taguchi and ANOVA" Procedia Technol., vol. 25, pp. 1106-1113, Jan. 2016. https://doi.org/10.1016/j.protcy.2016.08.217

[22] O. Ryabov, K. Mori, N. Kasashima, and K. Uehara, "An In-Process Direct Monitoring Method for Milling Tool Failures Using a Laser Sensor" CIRP Ann. - Manuf. Technol., vol. 45, no. 1, pp. $\quad 97-100, \quad$ Jan. $1996 . \quad$ https://doi.org/10.1016/S0007-8506(07)63024-8 
[23] R. P. H. Faassen, N. Van de Wouw, J. A. J. Oosterling, and H. Nijmeijer, "Prediction of regenerative chatter by modelling and analysis of high-speed milling" Int. J. Mach. Tools Manuf., vol. 43, no. 14, pp. 1437-1446, Nov. 2003. https://doi.org/10.1016/S0890-6955(03)00171-8

[24] M. Rantatalo, "Non-contact measurements and modelling of milling machine tool vibrations" Licent. thesis / LuleÂ Univ. Technol., 2006.

[25] T. Österlind, C. Frangoudis, and A. Archenti, "Operational Modal Analysis During Milling Of Workpiece, Fixed On A Stiffness Controllable Joint" Journal of Machine Engineering vol. 13, no. 2, pp. 69-78, 2013.

[26] H. Nakagawa, Y. Kurita, K. Ogawa, Y. Sugiyama, and H. Hasegawa, "Experimental Analysis of Chatter Vibration in End-Milling Using Laser Doppler Vibrometers" Int. J. Autom. Technol., vol. 2, no. 6, pp. 431-438, Nov. 2008. https://doi.org/10.20965/ijat.2008.p0431

[27] P. Norman, M. Bäckström, M. Rantatalo, A. Svoboda, and A. Kaplan, "A sophisticated platform for characterization, monitoring and control of machining" Meas. Sci. Technol., vol. 17, no. 4, pp. 847-854, Apr. 2006. https://doi.org/10.1088/0957-0233/17/4/032

[28] M. Béres and B. Paripás, "Comparison of two laser interferometric methods for the study of vibrations" Lect. Notes Mech. Eng., vol. PartF12, pp. 205-216, 2017. https://doi.org/10.1007/978-3-319-51189-4_20

[29] J. Majár, M. Béres, and E. Kovács, “Különbözö alátámasztások hatása a lézer doppleres mérések szisztematikus hibáira" 2019. https://doi.org/10.26649/musci.2019.024

[30] J. Munoa et al., "Chatter suppression techniques in metal cutting," CIRP Ann. - Manuf. Technol., vol. 65, no. 2, pp. 785-808, 2016. https://doi.org/10.1016/j.cirp.2016.06.004

[31] M. Norgia, D. Melchionni, and A. Pesatori, "Self-mixing instrument for simultaneous distance and speed measurement" Opt. Lasers Eng., vol. 99, pp. 31-38, Dec. 2017. https://doi.org/10.1016/j.optlaseng.2016.10.013

[32] B. J. Halkon and S. J. Rothberg, "Taking laser Doppler vibrometry off the tripod: correction of measurements affected by instrument vibration" Opt. Lasers Eng., vol. 91, pp. 16-23, Apr. 2017. https://doi.org/10.1016/j.optlaseng.2016.11.006

[33] N. A. Halliwell, "The laser torsional vibrometer: A step forward in rotating machinery diagnostics" J. Sound Vib., vol. 190, no. 3, pp. 399-418, Feb. 1996. https://doi.org/10.1006/jsvi.1996.0071

[34] P. Hosek, "Algorithm for signal drop-out recognition in IC engine valve kinematics signal measured by laser Doppler vibrometer" Opt. Laser Technol., vol. 44, no. 4, pp. 1101-1112, Jun. 2012. https://doi.org/10.1016/j.optlastec.2011.09.034

[35] L. E. Drain, The laser-Doppler technique. John Wiley \& Sons, 1980.

[36] K. Tatar, M. Rantatalo, and P. Gren, "Laser vibrometry measurements of an optically smooth rotating spindle" Mech. Syst. Signal Process., vol. 21, no. 4, pp. 1739-1745, May 2007. https://doi.org/10.1016/j.ymssp.2006.08.006

[37] J. R. Bell and S. J. Rothberg, "Laser vibrometers and contacting transducers, target rotation and six degree-of-freedom vibration: What do we really measure?" J. Sound Vib., vol. 237, no. 2 , pp. 245-261, Oct. 2000. https://doi.org/10.1006/jsvi.2000.3053

[38] S. J. Rothberg, J. R. Baker, and N. A. Halliwell, "On Laser Vibrometry of Rotating Targets: Effects of Torsional and In-Plane Vibration" J. Laser Appl., vol. 2, no. 1, pp. 29-36, Jan. 1990. https://doi.org/10.2351/1.4745250

[39] P. Martin and S. Rothberg, "Introducing speckle noise maps for Laser Vibrometry" Opt. Lasers 
Eng., vol. 47, no. 3-4, pp. 431-442, 2009. https://doi.org/10.1016/j.optlaseng.2008.06.010

[40] S. J. Rothberg, J. R. Baker, and N. A. Halliwell, "Laser vibrometry: Pseudo-vibrations" Journal of Sound and Vibration, vol. 135, no. 3. pp. 516-522, 22-Dec-1989. https://doi.org/10.1016/0022-460X(89)90705-0

[41] S. W. Courville and P. Sava, "toward orbital seismology: theory for speckle noise reduction in laser doppler vibrometer measurements on distant rough surfaces" 2020.

[42] J. Vass, R. Šmíd, R. B. Randall, P. Sovka, C. Cristalli, and B. Torcianti, “Avoidance of speckle noise in laser vibrometry by the use of kurtosis ratio: Application to mechanical fault diagnostics" Mech. Syst. Signal Process., vol. 22, no. 3, pp. 647-671, Apr. 2008. https://doi.org/10.1016/j.ymssp.2007.08.008 